\title{
Thyroid hormone signaling is highly heterogeneous during pre- and postnatal brain development
}

\section{Quignodon, C Legrand, N Allioli, A Guadaño-Ferraz'ㄹ, J Bernal' ${ }^{1}$, J Samarut and F Flamant}

Laboratoire de Biologie Moléculaire et Cellulaire de l'Ecole Normale Supérieure de Lyon, UMR CNRS 5665 LA INRA 913 , IFR128 Lyon Gerland, 46 allée d'Italie, 69364 Lyon cedex 07 France

${ }^{1}$ Instituto de Investigaciones Biomedicas Alberto Sols, Universidad Autonoma de Madrid, Madrid, Spain

(Requests for offprints should be addressed to F Flamant; Email: Frederic.Flamant@ens-lyon.fr)

\begin{abstract}
We have generated transgenic reporter mice to analyze the spatio-temporal distribution of thyroid hormone signaling during mouse brain development. The reporter system, utilizing a chimeric yeast Gal4 DNA-binding domain-thyroid hormone $\alpha$ ligand-binding domain fusion protein to drive lacZ expression, revealed that thyroid hormone signaling starts in the midbrain roof several days before the onset of thyroid gland function, and that it remains highly heterogeneous in the central nervous system throughout pre- and postnatal development. We speculate that this heterogeneity might provide neural cells with positional information during development.
\end{abstract}

Journal of Molecular Endocrinology (2004) 33, 467-476

\section{Introduction}

Thyroid hormone (3,5,3'-tri-iodothyronine; T3) is an essential regulator of brain development, congenital hypothyroidism resulting in severe and irreversible mental retardation. T3 directly activates gene expression by binding to thyroid hormone receptors (TRs) expressed from the two $T R a$ and TR $\beta$ genes. Like other nuclear receptors, including the closely related retinoic acid receptors, TRs act mainly as heterodimers with retinoid $\mathrm{X}$ receptor (RXR), and remain bound to DNA in the absence of hormone binding. Unliganded TR exert a negative influence on gene expression. This property explains why mice lacking both $T R a$ and TR $\beta$ genes are viable and fertile (Gothe et al. 1999, Gauthier et al. 2001) whereas mice homozygous for point mutations introduced in the $T R a$ gene die either in utero (Liu et al. 2003) or soon after birth (Kaneshige et al. 2000, Tinnikov et al. 2002, Flamant \& Samarut 2003). Upon T3 binding, interaction with corepressors are destabilized and TRs recruit several coactivator complexes (Hermanson et al. 2002). Although TRa, TR $\beta$, $R X R a, R X R \beta$ and $R X R \gamma$ display distinct expression patterns, at least one TR isoform and one RXR isoform are likely to be present at some level in most mammalian brain cells throughout development, likely to be as heterodimers (Bradley et al. 1989, 1992, 1994, Mellstrom et al. 1991).

In rodents, several neural populations have been shown to be sensitive to hypothyroidism during the pre- and postnatal periods (Bernal \& Nunez 1995, Koibuchi \& Chin 2000). However, the multiple and successive influences of $\mathrm{T} 3$ on brain cells remain poorly understood. When exactly T3 starts to act on brain cells is still unclear. We have shown previously that, in the chicken embryo, T3 originating from egg yolk is already present in the Hensen's node during neurulation (Flamant \& Samarut 1998). The situation in rodents is, however, more complex. Both T3 and its precursor thyroxine (T4), which is secreted by the thyroid gland, are detected in the embryo proper from gestational day 13 (E13). As the onset of fetal thyroid function occurs only at E17.5, this indicates that at least maternal $\mathrm{T} 4$ can cross the placenta (Obregon et al. 1984). Maternal hypothyroidism results in a reduction of embryo viability and weight, compromising brain develop- 
ment (Morreale de Escobar et al. 1995, Berbel et al. 2001), while maternal hypothyroxinemia (i.e. low T4 level with normal T3 level) selectively affects fetal brain histogenesis and neuroblast migration (Lavado-Autric et al. 2003). It is thus very likely that $\mathrm{T} 3$ in the fetal brain is mainly produced by outer ring deiodination of maternal T4. This reaction can be catalyzed by type 2 deiodinase, an enzyme encoded by the Dio2 gene which is expressed in the embryo (Galton et al. 2001). The effect of Dio2 expression can be counteracted by Dio3 expression, encoding type 3 deiodinase, which also occurs at specific locations in the placenta and fetus, and is responsible for $\mathrm{T} 4$ and $\mathrm{T} 3$ catabolism (Tsai et al. 2002).

At around E16, the appearance of the bloodbrain barrier and the choroid plexus-cerebrospinal fluid barrier introduces another level of regulation. While the blood--brain barrier is relatively impermeable to T3, T4 is transferred from the serum to the cerebrospinal fluid via the choroid plexus. As a result, it has been estimated that more than half of the $\mathrm{T} 3$ found in the postnatal brain results from local outer ring deiodination (van Doorn et al. 1983), Dio2 being expressed mainly in tanicytes and astrocytes (Guadano-Ferraz et al. 1997b). The brain compensates for low T3 levels by increasing Dio2 expression and local T3 synthesis (Guadano-Ferraz et al. 1999). By contrast, high T3 levels induce the expression of Dio3 and T3 degradation at different sites (Guadano-Ferraz et al. 1999, Tu et al. 1999). This autonomous regulation in the brain has two consequences. First, the distribution of T4, T3 and related metabolites in the adult rodent brain is heterogeneous (Dratman \& Gordon 1996, Rozanov \& Dratman 1996, Pinna et al. 2002). Secondly, the T3 level is much more stable in the brain than in the serum. For example, T3 is still present in the brain several weeks after thyroidectomy (Morreale de Escobar et al. 1995). Anterograde axonal transport of T3, indirectly demonstrated for noradrenergic neurons, could potentially deliver T3 to distant locations (Gordon et al. 1999) and might provide another level of regulation to T3 distribution.

All these observations suggest that T3 signaling in the developing brain can be modulated at several levels by both intracellular and extracellular events and does not directly reflect $\mathrm{T} 3$ content in maternal, fetal or newborn serum. To directly visualize T3 signaling, we have produced transgenic reporter mice, using a highly specific one-hybrid system. The ability of this system to faithfully reflect T3 signaling has been previously demonstrated in vitro (Flamant \& Samarut 1998) and in vivo for several other nuclear hormone receptors (Solomin et al. 1998, Mata De Urquiza et al. 1999, Wallen-Mackenzie et al. 2003). Analysis of these reporter mice allowed us to describe precisely for the first time the spatio-temporal pattern of T3 signaling in the brain which appears to be highly dynamic and heterogeneous. These data suggested that T3 should not only be considered as a trophic factor but might also constitute an informative signal able to control cell fate during brain development.

\section{Materials and methods}

\section{Reporter plasmid}

The plasmid pFIND-T3 (Feedback Inducible Nuclear-Driven reporter for T3) was generated by replacing the XhoI-NheI restriction fragment of pFIND-RA, reporting for retinoids, containing most of the Gal4-RAR reading frame (Mata De Urquiza et al. 1999) by the equivalent portion (XhoI-XbaI) of Gal4-TR $\alpha$ (Flamant \& Samarut 1998). pFIND-T3 was transfected together with pBKS - (Stratagene, San Diego, CA, USA) as carrier DNA (20 ng pFIND-T3/1 $\mu \mathrm{g}$ pBKS - ) into COS cells (Fugene; Roche Applied Science, Meylan, France). LacZ transient expression was measured $48 \mathrm{~h}$ later in cell lysates using OrthoNitro-Phenyl-Galactopyranoside (Sigma). pSG5RXR encodes the human RXR $\alpha$ cDNA from an SV40 transcription promoter (Stratagene).

\section{Animals}

Transgenic OF1 founders were recognized by Southern blotting. Later identification of FINDT3 animals relied on PGR amplification of the lacZ sequence. Animal carrying the $\operatorname{Pax} 8$ knockout mutation (Mansouri et al. 1998) were screened as described (Flamant et al. 2002). To increase brain hormonal level, a mixture of T4 and T3 (Sigma) was injected each day for 5 days (i.p. injection of $100 \mu \mathrm{l} ; 200 \mu \mathrm{g} / \mathrm{kg}$ T3 and $2 \mathrm{mg} / \mathrm{kg} \mathrm{T} 4)$ between postnatal day $8(\mathrm{P} 8)$ and $\mathrm{P} 12$. Xgal (5-bromo4-chloro-3-indolyl- $\beta$-D-galactoside) staining was performed after paraformaldehyde fixation for $16 \mathrm{~h}$ at $30{ }^{\circ} \mathrm{C}$ for at least ten samples in each condition 
with identical results. All experiments were conducted in accordance with accepted standards of animals care.

\section{RNA analysis}

RNA was extracted using the Geneelute kit (Sigma), followed by DNAaseI and proteinase $\mathrm{K}$ digestion, phenol/ $\mathrm{CHCl}_{3}$ extraction and ethanol precipitation. For quantitative RT-PCR, cDNA was prepared from $1 \mu \mathrm{g}$ of individual RNA samples (not pooled) using AMV reverse transcriptase (Promega, Charbonnieres, France). Diluted cDNA $\left(1 / 10\right.$ to $1 / 100$ to keep threshold cycle $\left(\mathrm{G}_{\mathrm{T}}\right)$ values between 20 and 30) was amplified by PGR in the presence of Sybr green (Roche Applied Science) using a real-time PCR Opticon machine (MJ Research, Reno, NV, USA) with the following oligonucleotide primers using the acidic ribosomal phosphoprotein PO gene (36B4) mRNA as an internal reference: 5'-GAAGATGGGACTCGTG AGGGTA and 5'-GCTTGAGGAGAATGACGG AGTC for Dio2; 5'-TGAACAGTGAAGG GGAG GAG and 5'-ATGCGACAGGGCTTTGAGAG AG for Dio3; 5'-CGCACGTTGTGTCGAGTC TTT and 5'-ACG TCGTTCTTCGAGGGTTT for 36B4; 5'-CGGTTCTGCTCAATCAGG and 5'-GATGCGGTCACAGATAGATTGG for Gal4TRa.

Serial dilutions of a cDNA prepared from a pool of P15 whole brain RNA (non-transgenic OF1 except for Gal4-TRa where FINDT3A mice were used) was used to build a standard curve and verify that amplification efficiency was superior to $90 \%$. Quantification was performed using the $\Delta \Delta \mathrm{C}_{\mathrm{T}}$ method (Livak \& Schmittgen 2001).

Dio2 and Dio3 expression was analyzed by in situ hybridization in E15.5 OF1 fetuses using 35S-radiolabeled probes as previously described (Guadano-Ferraz et al. 1997b, Escamez et al. 1999).

\section{Quantification of T3 in brain extracts}

T3 was partially purified from pools of ten FINDT3B brain fractions by ion-exchange chromatography (Obregon et al. 1984). Dry extracts were suspended in culture medium and placed on pFIND-T3 transfected COS cells. Culture medium serum was treated by anion exchange chromatography (AG1-X8; Biorad, Marnes-la-Coguette, France) for T3 depletion (Belote et al. 1970).

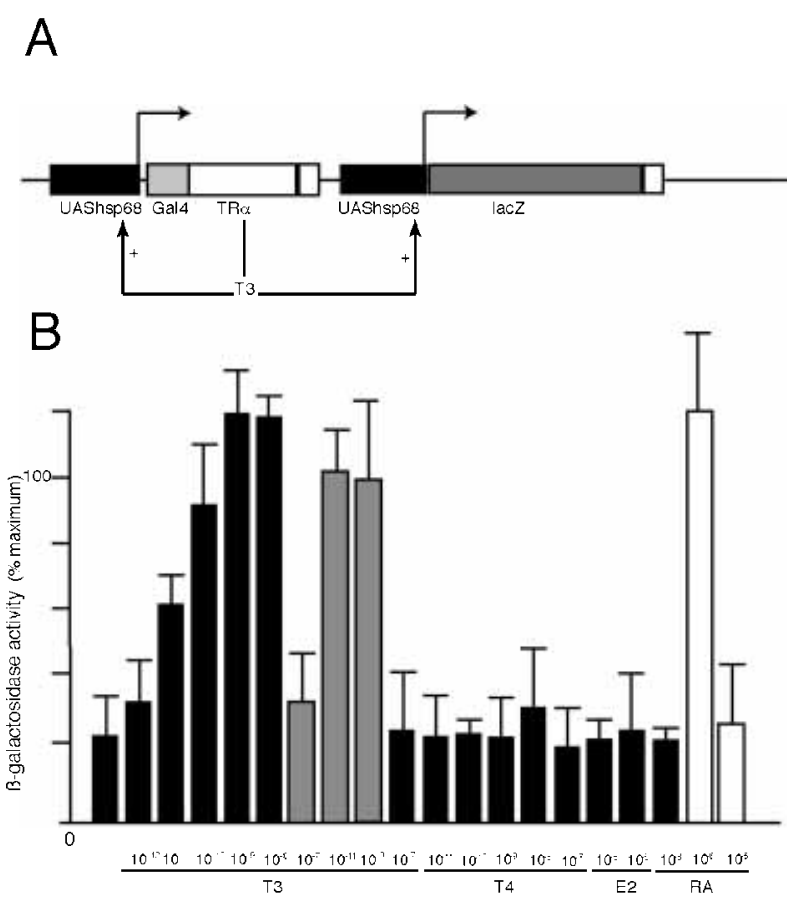

Figure 1 The Gal4-TR $\alpha$ reporter system. (A) The pFIND-T3 plasmid carries two transcription units. One ensures the expression of a Gal4-TR $\alpha$ hybrid receptor able to bind Gal4 UAS and to recruit transcription coactivators on the TR $\alpha$ ligand-binding domain in a T3-dependent manner (rat TR $\alpha$ 1; amino acids 126-410). The hybrid receptor controls the expression of both the lac $Z$ reporter gene and its own expression. (B) lacZ transient expression after transfection of COS cells with pFIND-T3 (solid bars), pFIND-T3+pSG5- RXR (shaded bars) or pFIND-RA (open bars). A significant response was observed from $10^{-11} \mathrm{M} \mathrm{T3}$, a concentration lower than the one found in normal serum. Maximum retinoic acid activation of pFIND-RA in the same conditions is given for comparison. Expression is insensitive to retinoic acid and estrogen, and is sensitive to T4 at high molarity only. RXR overexpression has no significant influence.

\section{Results}

\section{Generation of transgenic mice with a reporter system for T3 signaling}

We adapted the system used to trace RAR ligands (Mata De Urquiza et al. 1999) for TR by replacing the RAR ligand-binding domain of Gal4-RAR with a TRa1 cDNA fragment encompassing the hinge and the ligand-binding domain, to create a Gal4-TR $\alpha 1$ hybrid receptor. The system is independent of endogenous TR (Fig. 1A). The hybrid receptor is able to bind Gal4 upstream activation 

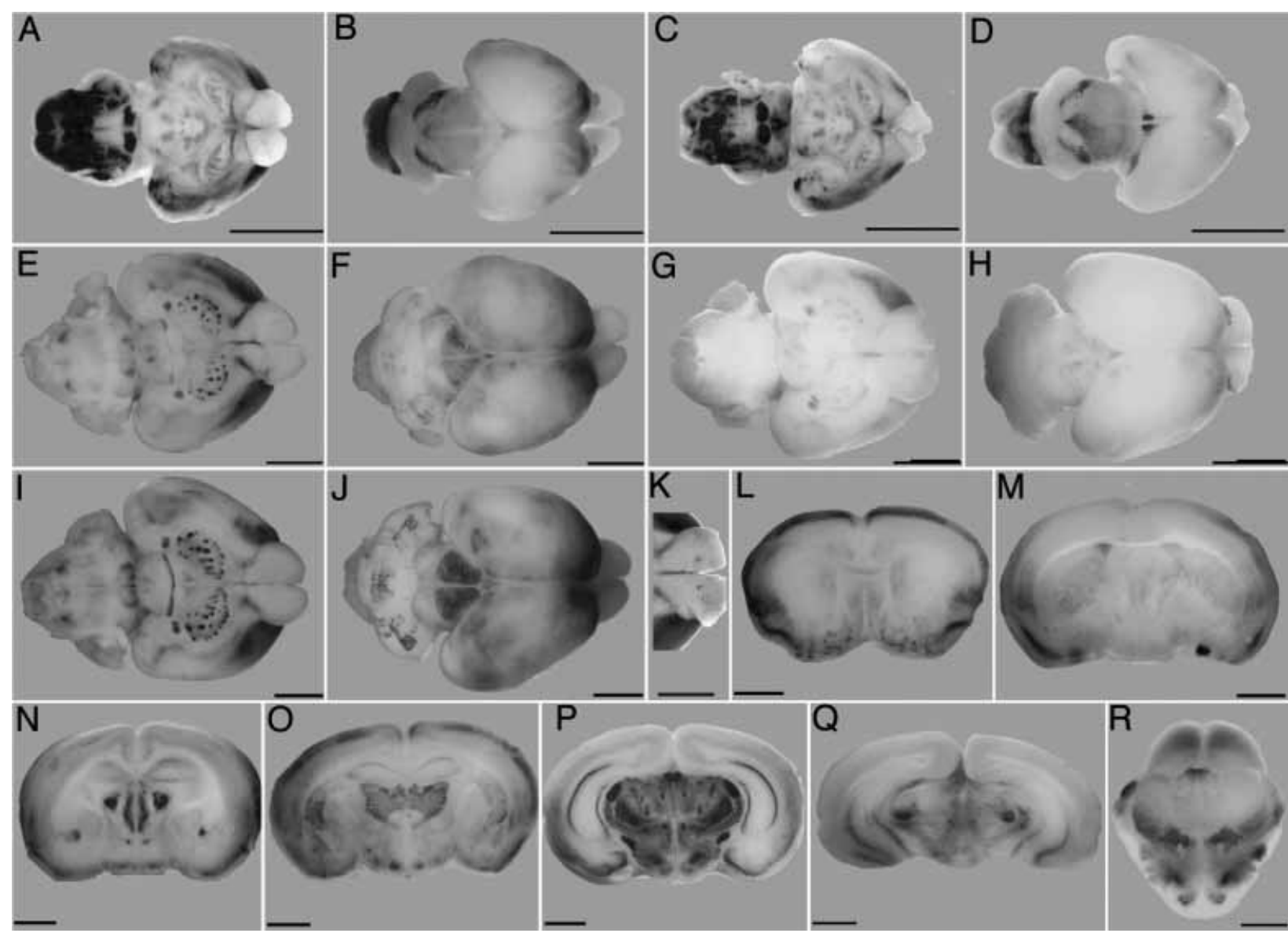

Figure 2 Postnatal expression of the lacZ reporter transgene. (A and B) FINDT3A brain at P2, ventral and dorsal view; (C and D) FINDT3A brain at P2, ventral and dorsal view; (E and F) FIND-T3B brain at P8, ventral and dorsal view; (G and $\mathrm{H}$ ) Pax8 ${ }^{-/-}$FINDT3B hypothyroid mice at P8; (I and J) Pax8 ${ }^{-/-}$FINDT3B hypothyroid mice treated for 5 days with T4 and T3; $(K)$ hyperthyroid FINDT3B olfactory bulbs at P15, ventral view (scattered staining is not observed in control animals); and (L-R) coronal sections of P15 FINDT3A brain at the approximate following positions, relative to Bregma line: L, 1.5; M, 0.8; N, $-0.5 ; \mathrm{O},-1 ; \mathrm{P},-2.5 ; \mathrm{Q},-3 ; \mathrm{R},-5$ (Franklin \& Paxinos 1997). Bars represent $2 \mathrm{~mm}$. High resolution figures are available at www.ens-lyon.fr/LBMC

sequence (UAS) and to activate the lacz gene only when activated by T3. This system needs both T3 and coactivators to function properly. The feedback-inducible expression of Gal4-TR $\alpha 1$ ensures a high sensitivity. The transient expression assay demonstrates that pFIND-T3 activation by T3 is similar to that of pFIND-RA (Mata De Urquiza et al. 1999) by retinoic acid, and that the system is sensitive to $10^{-11} \mathrm{M}$ T3 in cultured COS cells (Fig. 1B). As expected from previous results (Flamant \& Samarut 1998), expression was not sensitive to RXR overexpression, addition of retinoic acid or estradiol. As for $\operatorname{TR} \alpha$, it was induced by T4 only at high molarity. The
pFIND-T3 plasmid was injected into mouse fertilized oocytes and two transgenic lines were derived, called FINDT3A and FINDT3B, differing only by the transgene integration site and copy number, roughly estimated by quantitative autoradiography to 5 and 20 copies respectively (data not shown).

\section{Transgene expression pattern is heterogeneous and depends on T3 availability}

Xgal staining was performed on whole brains of FINDT3A and FINDT3B mice at several stages of postnatal development (Fig. 2A-F), and this 
revealed that the expression pattern of lac $Z$ was highly similar in both strains. The postnatal expression pattern was stable over time, the decrease observed in the cerebellum external granular layer corresponding to the progressive disappearance of this structure. We first confirmed that lac 2 expression depends on T3 by crossing FINDT3B mice with $\mathrm{PaxO}^{+/-}$mice to generate FINDT3B/Pax $8^{-/-}$mice devoid of thyroid follicular cells and thus of T3 (Mansouri et al. 1998, Flamant et al. 2002). lac Z expression was found to be very low at P2, P8 and P15 in the large majority of these mice (eight out of ten) (Fig. 2G and H), and was rescued after 5 days of T4/T3 treatment (Fig. 2I and J). Although this was not precisely addressed, the persistence of lac Z expression in two FINDT3B/Pax $8^{-/-}$mice might reveal that some Pax $8^{-1-}$ mice retain the ability to make a small amount of T3. Rendering the mothers and offspring hypothyroid by propyl-thio-uracyl feeding confirmed that transgene expression was, as expected, strictly dependent on T3 (data not shown). We also verified that the absence of staining, observed mainly in the cerebellum inner granular layer and olfactory bulbs, reflects weak T3 signaling rather than a systematic bias in transgene expression. When we rendered FINDT3B mice hyperthyroid by five daily injections of T4/T3, starting at P10, lacz expression increased in a visible manner even in the cerebellum and olfactory bulbs (Fig. 2K) without becoming ubiquitous. We expected that lacZ and Gal4-TRa expression would follow the same expression pattern, because they are both driven by the same inducible promoter. Quantitative RT-PGR confirmed that Gal4-TRa expression was higher in the piriform cortex and colliculus than in the cerebellum and olfactory bulbs $(100 \%, 43 \pm 10 \%$, $22 \pm 6 \%$ and $18 \pm 5 \%$ respectively in FINDT $3 \mathrm{~A}$ at $\mathrm{P} 15 ; n=4)$. Taken together, these data indicated that, at least in the brain, the FINDT3 reporter system reflects T3 signaling. Staining of brain slices allowed for a precise and complete description of the lac Z expression pattern (Fig. 2L-R and Table 1) and confirmed the excellent correlation between the FINDT3A and FINDT3B staining patterns. Discrepancies between the two strains were observed mainly in the inferior colliculus and the Purkinje cells, where expression was only observed in FINDT3B animals, and the cortex, where the expression was broader in FINDT3B. Although T3
Table 1 Comparison between FINDT3A and FINDT3B brains for lacZ postnatal expression (P15)

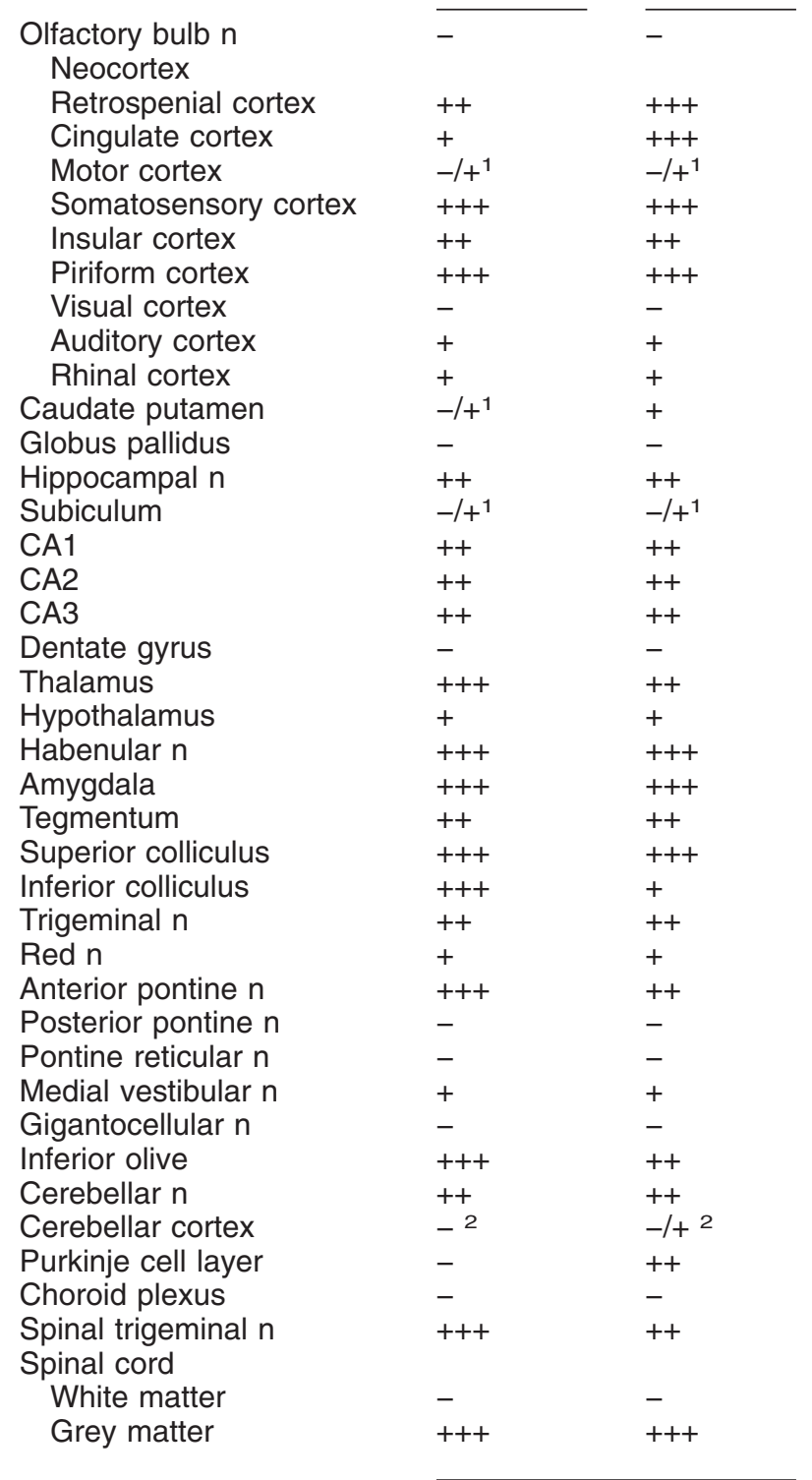

\section{FINDT3A FINDT3B}

$\mathrm{n}=$ nucleus. ${ }^{1}$ Heterogeneous expression within the structure. 2External granular layer at P8: FINDT3A +, FINDT3B ++.

signaling is known to occur in most if not all cell types, Xgal staining in non-neural tissues and fibroblasts cultured from transgenic embryos was usually weak, suggesting that the reporter system is more efficient in neural tissues. More precisely, double immunostaining of brain sections with Tuj1, an antibody which labels neurons, and 

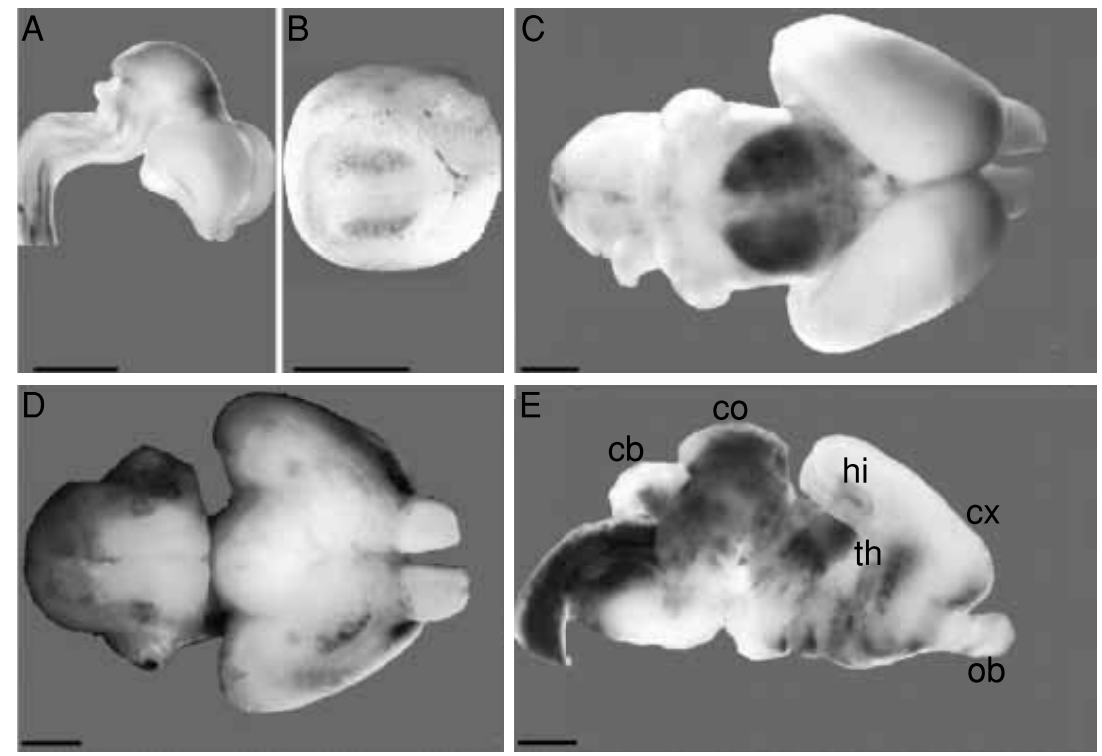

Figure 3 Fetal expression of the lacZ reporter transgene. (A) E15.5 FINDT3A fetal brain; (B) top view of E15.5 FINDT3B fetus, expression is visible in the mesencephalon; (C and D) E17.5 FINDT3A brain, dorsal and ventral view; (E) sagittal section of an E17.5 FINDT3B fetal brain, prospective colliculus (co), hippocampus (hi), thalamus (th) are stained but not lateral cortex (cx), olfactory bulbs (ob) and cerebellum (cb). The ventral telencephalon-stained area corresponds to the future piriform cortex. Bars represent $1 \mathrm{~mm}$. High resolution figures are available at www.ens-lyon.fr/LBMC/

anti- $\beta$-galactosidase antibodies indicated that expression was mainly observed in neurons $(>95 \%$; data not shown).

\section{Temporal pattern of T3 signaling in brain}

We performed Xgal staining at various stages of FINDT3 embryonic development to evaluate when T3 signaling first appears in the developing brain. At E13.5 and E14.5, reporter expression was absent from the neural tube (data not shown). At E15.5, lacz expression started in the roof of the midbrain (Fig. 3A and B). At E17.5 the expression pattern became more complex, showing staining in several areas (Fig. 3C-E). As fetal thyroid does not secrete hormone before E17.5, these results reflect either a direct maternal supply of T3 or a transplacental transfer of $\mathrm{T} 4$ followed by a fetal deiodination into T3. In summary, the most striking observation that we made was that T3 signaling starts early during brain development in the midbrain roof where it remains elevated after birth. It is also high in the piriform cortex and thalamus whereas it is constantly very low in the cerebellum and olfactory bulbs.

\section{Local thyroid hormone level and deiodinase gene expression patterns}

A simple explanation for the lac $Z$ heterogeneous expression would be that local T3 concentration dictates transgene expression. We used pFIND-T3 transfected cells to measure T3 purified from three brain areas at P15. In agreement with previous data (Pinna et al. 2002) and as expected from lacZ expression, T3 was found to be high in anterior cortex $(1500 \mathrm{fmol} / \mathrm{g})$ and colliculus $(6000 \mathrm{fmol} / \mathrm{g}$ ) but low in cerebellum (500 fmol/g). Dio2 expression is mainly responsible for local conversion of T4 into T3 and Dio3 expression for T3 catabolism. We thus used quantitative RT-PGR and in situ RNA hybridization (Fig. 4) to assess Dio2 and Dio3 expression and complete the published data (Guadano-Ferraz et al. 1997a, 1999, Escamez et al. 1999, Tu et al. 1999, Tsai et al. 2002). As in the postnatal brain, Dio2 expression is found at E15.5 


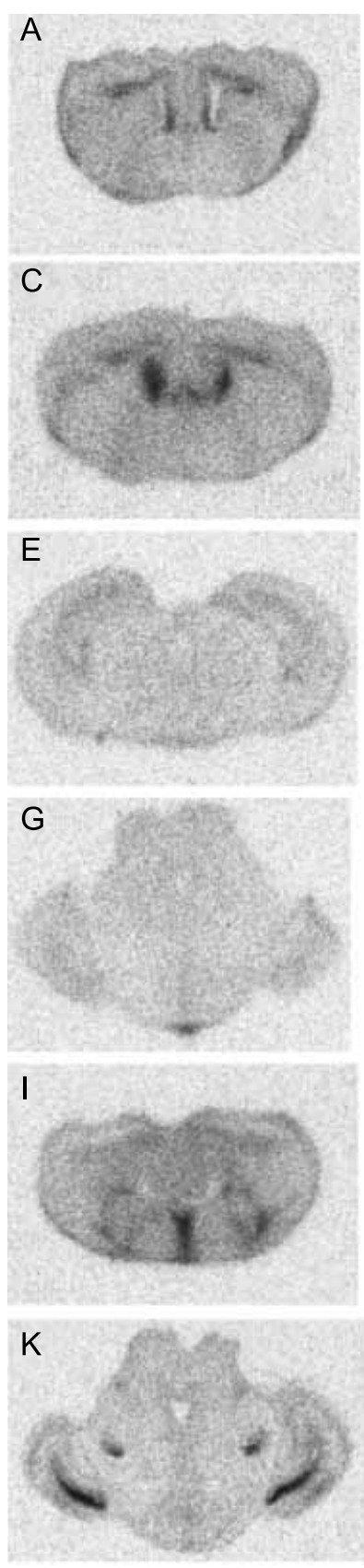

B
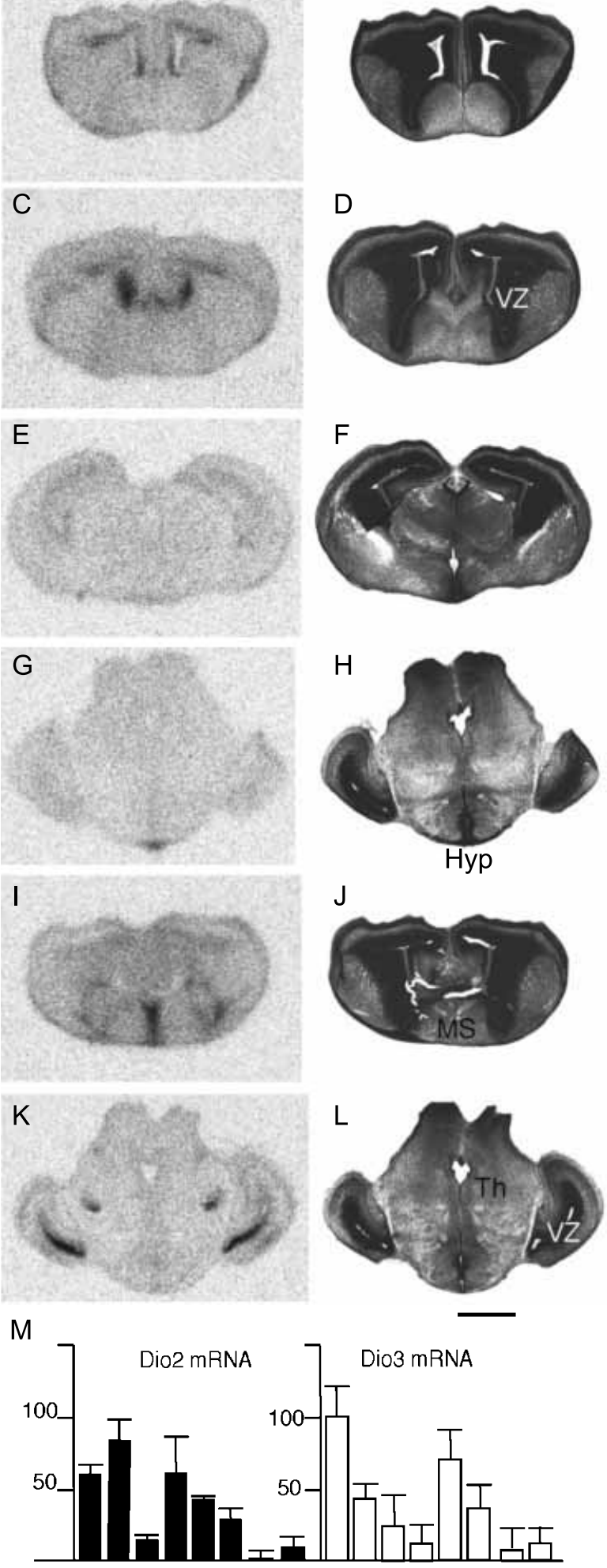

$\begin{array}{llllllllllllllll}1 & 2 & 3 & 4 & 5 & 6 & 7 & 8 & 1 & 2 & 3 & 4 & 5 & 6 & 7 & 8\end{array}$

Xgal $\underset{+}{+}+\underset{+}{+}+\underset{+}{+}$ in the medial and dorsal ventricular layers in the walls of the third ventricle and the basal hypothalamus (Fig. 4A, C and G), Dio3 expression is in the medial septal area, the dorso-lateral ventricular zone and the thalamus (Fig. 4I and K). Dio2 and Dio3 expression have thus the potential to generate a heterogeneous $\mathrm{T} 3$ distribution in the fetal brain before the onset of thyroid function, but the midbrain roof, where the FIND-T3 reporter gene is first expressed, is not identifiable by a distinct Dio2/Dio3 expression pattern. After birth, RT-PCR confirmed that Dio2 expression is low in the cerebellum and high in the frontal cortex and colliculus correlating with reporter gene expression (Fig. 4M) but a precise examination of the published Dio2/Dio3 expression pattern suggests that, as in the fetal brain, additional factors influence the signaling pattern in a significant manner.

\section{Discussion}

This FINDT3 transgenic reporter system proved to be highly responsive to thyroid hormone in neuronal cells. It is not dependent on endogenous receptors but requires transcription coactivators. Other protein-protein interactions mediated by the ligand-binding domain that is conserved in the hybrid Gal4-TR $\alpha$ receptor can take place, and the reporter system readout is thus likely to closely resemble the endogenous signaling pattern. The possibility remains, however, that interactions occurring in the N-terminal domains of TR and variations in TR isoforms expression might

Figure 4 Type 2 (Dio2) and type 3 (Dio3) deiodinase expression. RNA in situ hybridization was performed at E15.5 on OF1 embryos. (A, C, E and G) Dio2 and (B, $\mathrm{D}, \mathrm{F}$ and $\mathrm{H}$ ) Nissl staining. Places of high Dio2 expression were ventricular zones (VZ) and hypothalamus (Hyp). (I-K) Dio3. (J-L) Nissl staining. Places of high Dio3 expression were ventricular zones, thalamus (Th) and the medial septal area (MS). Bar represents $1 \mathrm{~mm}$. (M) Quantitative RT-PCR. Dio2 and Dio3 expression at P15 in piriform cortex (1), lateral cortex (2), cerebellum (3), colliculus (4), hypothalamus (5), pons (6), E15.5 midbrain (Dio2 3.3 \pm 2 ) (7) and E15.5 forebrain (Dio2 $9 \pm 4$ ) (8). $(n=4)$. P15 euthyroid whole brain RNA was used as a reference. Results are expressed by comparison with this reference. The relative intensity of Xgal staining, reported from Table 1 , is indicated. 
generate another level of regulation, not detected by the FINDT3 system.

Our data revealed that T3 signaling in brain follows a complex pattern during neural development starting at E15.5. The onset of endogenous T3 signaling might occur slightly earlier, because the accumulation of $\beta$-galactosidase in a selfinducible system could be delayed. One striking and unexpected feature of the signaling pattern is its first appearance and persistence in the midbrain. After birth, sharp transitions in reporter gene expression are maintained. Two locations of persistently low signaling are the olfactory bulbs and the cerebellum inner granular layer. Interestingly, these are precisely the two areas where the consequences of congenital hypothyroidism are more visible (Lauder 1977, Calza et al. 2000, Koibuchi \& Chin 2000). It is noticeable, however, that lac Z expression was found in external granular cells, a neuronal population which is known, together with Purkinje cells, to be directly sensitive to hypothyroidism. The possibility remains that T3 action in the cerebellum is partially indirect and results from anterograde axonal transport of T3-induced neurotropins toward the cerebellum (von Bartheld \& Butowt 2000).

Spatio/temporal variations in T3 signaling could be due to changes in T3 metabolism, T3 transport and intracellular factors. Several considerations suggest that T3 availability is most likely the limiting factor: (1) the first appearance of lacZ expression during development coincides with the appearance of $\mathrm{T} 3$ in the embryo (Obregon et al. 1984); (2) increasing the level of T3 results in a broader lacZ expression; and (3) direct measurement of T3 content shows a good coincidence with reporter expression. If the signaling pattern mainly reflects T3 distribution the underlying mechanism generating this distribution is unclear, because T3 metabolism is complex (Pinna et al. 2002) and not fully understood (Bianco et al. 2002). From the ventricular expression of Dio2, we could expect a high reporter gene expression in neighboring areas, but this was not the case. T3 transport (Gordon et al. 1999) might thus also influence T3 distribution.

Detailed analysis reveals discrepancies between T3 distribution, visualized by histochemistry (Gordon et al. 1999), and reporter expression. Furthermore, expression does not become ubiquitous in hyperthyroid brains. These are indications that intracellular factors might also influence transgene expression. For example, many anion transporters can modulate $\mathrm{T} 3$ diffusion to the nucleus (Abe et al. 2002). Alternatively, components of several coactivator complexes (Hermanson et al. 2002) could display a restricted expression. We attempted to incriminate the Hairless corepressor alone because it is highly expressed in cerebellum and inducible by T3 (Thompson \& Potter 2000, Potter et al. 2002). Introducing the Hairless mutation in FINDT3 mice did not modify lac Z expression, ruling out the possibility that Hairless alone influences reporter gene expression (data not shown). It is more likely that the complex expression pattern that we observed translates a complex combination of underlying mechanisms.

Given that early maternal hypothyroidism prevents embryonic development, addressing the exact importance of early T3 signaling on midbrain development will necessitate a precise analysis of the lethal TRa knockin mutations. T3 is generally considered as a trophic factor whereas retinoic acid, a vitamin A derivative which is not chemically related to T3, has been originally proposed to be a morphogen (Wolpert 1989). Although it is now apparent that the original morphogen definition does not apply to retinoic acid, it is well established that the local variations in retinoic acid signaling are informative for cell differentiation and field patterning at several steps of development (Maden 2002). Retinoic acid binds RARs, which are the closest relatives of TR within the nuclear hormone superfamily. The two receptor types share common target genes, including the neuron-specific neurogranin gene (Guadano-Ferraz et al. 1997a, Husson et al. 2003). They also share many coactivators and corepressors. The data presented here have demonstrated that T3 signaling can also vary at short distance in the developing brain. We propose that, as for retinoic acid, T3 local concentration provides the brain cells with positional information and can thus control patterning and differentiation events during neural development.

\section{Acknowledgements}

We thank Thomas Perlmann for the gift of plasmids, A Shumann, JM Vanacker and K Gauthier for critical reading of the manuscript, and Nadine Aguilera for breeding the mice. This work 
was supported by the Association pour la Recherche contre le Cancer, de Ligue Nationale contre le Cancer, the Human Frontier Scientific Program (RGO347/1999.M) and the CASCADE European Network of Excellence.

\section{References}

Abe T, Suzuki T, Unno M, Tokui T \& Ito S 2002 Thyroid hormone transporters: recent advances. Trends in Endocrinology and Metabolism 13 215-220.

von Bartheld CS \& Butowt R 2000 Expression of neurotrophin-3 (NT-3) and anterograde axonal transport of endogenous NT-3 by retinal ganglion cells in chick embryos. Fournal of Neuroscience $\mathbf{2 0}$ 736-748.

Belote A, Rebelote B \& Dissdeuder C 1970 Serum hormonal depletion. Analytical Biochemistry 2 45-54.

Berbel P, Auso E, Garcia-Velasco JV, Molina ML \& Camacho M 2001 Role of thyroid hormones in the maturation and organisation of rat barrel cortex. Neuroscience 107 383-394.

Bernal J \& Nunez J 1995 Thyroid hormones and brain development. European Fournal of Endocrinology 133 390-398.

Bianco AC, Salvatore D, Gereben B, Berry MJ \& Larsen PR 2002 Biochemistry cellular and molecular biology and physiological roles of the iodothyronine selenodeiodinases. Endocrine Reviews 23 38-89.

Bradley DJ, Young WS 3rd \& Weinberger C 1989 Differential expression of alpha and beta thyroid hormone receptor genes in rat brain and pituitary. PNAS 86 7250-7254.

Bradley DJ, Towle HC \& Young WS 3rd 1992 Spatial and temporal expression of alpha- and beta-thyroid hormone receptor mRNAs including the beta 2 -subtype in the developing mammalian nervous system. Fournal of Neuroscience 12 2288-2302.

Bradley DJ, Towle HC \& Young WS 3rd 1994 Alpha and beta thyroid hormone receptor (TR) gene expression during auditory neurogenesis: evidence for TR isoform-specific transcriptional regulation in vivo. PNAS $91439-443$.

Calza L, Forrest D, Vennstrom B \& Hokfelt T 2000 Expression of peptides and other neurochemical markers in hypothalamus and olfactory bulb of mice devoid of all known thyroid hormone receptors. Neuroscience 101 1001-1012.

van Doorn J, van der Heide D \& Roelfsema F 1983 Sources and quantity of 3,5,3'-triiodothyronine in several tissues of the rat. Fournal of Clinical Investigation 72 1778-1792.

Dratman MB \& Gordon JT 1996 Thyroid hormones as neurotransmitters. Thyroid 6 639-647.

Escamez MJ, Guadano-Ferraz A, Cuadrado A \& Bernal J 1999 Type 3 iodothyronine deiodinase is selectively expressed in areas related to sexual differentiation in the newborn rat brain. Endocrinology 140 5443-5446.

Flamant F \& Samarut J 1998 Involvement of thyroid hormone and its alpha receptor in avian neurulation. Developmental Biology 197 $1-11$.

Flamant F \& Samarut J 2003 Thyroid hormone receptors: lessons from knockout and knock-in mutant mice. Trends in Endocrinology and Metabolism 14 85-90.

Flamant F, Poguet AL, Plateroti M, Chassande O, Gauthier K, Streichenberger N, Mansouri A \& Samarut J 2002 Congenital hypothyroid Pax8 $(-/-)$ mutant mice can be rescued by inactivating the TRalpha gene. Molecular Endocrinology 16 24-32.

Franklin KBJ \& Paxinos G 1997 The Mouse Brain in Stereotaxic Coordinates. San Diego: Academic Press.

Galton VA, Martinez E, Hernandez A, St Germain EA, Bates JM \& St Germain DL 2001 The type 2 iodothyronine deiodinase is Endocrinology 142 2123-2128.

Gauthier K, Plateroti M, Harvey CB, Williams GR, Weiss RE, Refetoff S, Willott JF, Sundin V, Roux JP, Malaval L, Hara M, Samarut J \& Chassande O 2001 Genetic analysis reveals different functions for the products of the thyroid hormone receptor alpha locus. Molecular and Cellular Biology 21 4748-4760.

Gordon JT, Kaminski DM, Rozanov CB \& Dratman MB 1999 Evidence that $33^{\prime} 5$-triiodothyronine is concentrated in and delivered from the locus coeruleus to its noradrenergic targets via anterograde axonal transport. Neuroscience 93 943-954.

Gothe S, Wang Z, Ng L, Kindblom JM, Barros AC, Ohlsson C, Vennstrom B \& Forrest D 1999 Mice devoid of all known thyroid hormone receptors are viable but exhibit disorders of the pituitary-thyroid axis growth and bone maturation. Genes and Development 13 1329-1341.

Guadano-Ferraz A, Escamez MJ, Morte B, Vargiu P \& Bernal J $1997 a$ Transcriptional induction of RC3/neurogranin by thyroid hormone: differential neuronal sensitivity is not correlated with thyroid hormone receptor distribution in the brain. Brain Research. Molecular Brain Research 49 37-44.

Guadano-Ferraz A, Obregon MJ, St Germain DL \& Bernal J $1997 b$ The type 2 iodothyronine deiodinase is expressed primarily in glial cells in the neonatal rat brain. PNAS 94 10391-10396.

Guadano-Ferraz A, Escamez MJ, Rausell E \& Bernal J 1999 Expression of type 2 iodothyronine deiodinase in hypothyroid rat brain indicates an important role of thyroid hormone in the development of specific primary sensory systems. Fournal of Neuroscience 19 3430-3439.

Hermanson O, Glass CK \& Rosenfeld MG 2002 Nuclear receptor coregulators: multiple modes of modification. Trends in Endocrinology and Metabolism 13 55-60.

Husson M, Enderlin V, Alfos S, Feart C, Higueret P \& Pallet V 2003 Triiodothyronine administration reverses vitamin A deficiency-related hypo-expression of retinoic acid and triiodothyronine nuclear receptors and of neurogranin in rat brain. British Fournal of Nutrition 90 191-198.

Kaneshige M, Kaneshige K, Zhu X, Dace A, Garrett L, Carter TA, Kazlauskaite R, Pankratz DG, Wynshaw-Boris A, Refetoff S, Weintraub B, Willingham MC, Barlow C \& Cheng S 2000 Mice with a targeted mutation in the thyroid hormone beta receptor gene exhibit impaired growth and resistance to thyroid hormone. PNAS 97 13209-13214.

Koibuchi N \& Chin WW 2000 Thyroid hormone action and brain development. Trends in Endocrinology and Metabolism 11 123-128.

Lauder JM 1977 The effects of early hypo- and hyperthyroidism on the development of rat cerebellar crotex. III Kinetics of cell proliferation in the external granular layer. Brain Research 126 $31-51$.

Lavado-Autric R, Auso E, Garcia-Velasco JV, Arufe Mdel C, Escobar del Rey F, Berbel P \& Morreale de Escobar G 2003 Early maternal hypothyroxinemia alters histogenesis and cerebral cortex cytoarchitecture of the progeny. Fournal of Clinical Investigation 111 1073-1082.

Liu YY, Schultz JJ \& Brent GA 2003 A thyroid hormone receptor alpha gene mutation $(\mathrm{P} 398 \mathrm{H})$ is associated with visceral adiposity and impaired catecholamine-stimulated lipolysis in mice. Fournal of Biological Chemistry 278 38913-38920.

Livak JL \& Schmittgen TD 2001 Analysis of relative gene expression data using real-time quantitative PCR and the 2-DDCT method. Methods 25 402-408.

Maden M 2002 Retinoid signalling in the development of the central nervous system. Nature Reviews in Neuroscience 3 843-853.

Mansouri A, Chowdhury K \& Gruss P 1998 Follicular cells of the thyroid gland require Pax8 gene function. Nature Genetics 19 87-90. 
Mata De Urquiza A, Solomin L \& Perlmann T 1999 Feedback-inducible nuclear-receptor-driven reporter gene expression in transgenic mice. PNAS 96 13270-13275.

Mellstrom B, Naranjo JR, Santos A, Gonzalez AM \& Bernal J 1991 Independent expression of the alpha and beta c-erbA genes in developing rat brain. Molecular Endocrinology 5 1339-1350.

Morreale de Escobar G, Pastor R, Obregon MJ \& Escobar del Rey F 1995 Effect of maternal hypothyroidism on the weight and thyroid hormone content of rat embryonic tissues before and after onset of fetal thyroid function. Endocrinology 117 1890-1900.

Obregon MJ, Mallol J, Pastor R, Morreale de Escobar G \& Escobar del Rey F 1984 L-thyroxine and 353'-triiodo-L-thyronine in rat embryos before onset of fetal thyroid function. Endocrinology 114 305-307.

Pinna G, Brodel O, Visser T, Jeitner A, Grau H, Eravci M, Meinhold H \& Baumgartner A 2002 Concentrations of seven iodothyronine metabolites in brain regions and the liver of the adult rat. Endocrinology 143 1789-1800.

Potter GB, Zarach JMI, Sisk JM \& Thompson CC 2002 The thyroid hormone-regulated corepressor hairless associates with histone deacetylases in neonatal rat brain. Molecular Endocrinology $162547-2560$.

Rozanov CB \& Dratman MB 1996 Immunohistochemical mapping of brain triiodothyronine reveals prominent localization in central noradrenergic systems. Neuroscience 74 897-915.

Solomin L, Johansson CB, Zetterstrom RH, Bissonnette RP, Heyman RA, Olson L, Lendahl U, Frisen J \& Perlmann T 1998 Retinoid-X receptor signalling in the developing spinal cord. Nature 395 398-402.
Thompson CC \& Potter GB 2000 Thyroid hormone action in neural development. Cerebral Cortex 10 939-945.

Tinnikov A, Nordström K, Thoren P, Kindblom JM, Malin S, Rozell B, Adams M, Rajanayagam O, Petterson S, Ohlsson C, Chatterjee K \& Vennstrom B 2002 Retardation of post-natal development caused by a negatively acting thyroid receptor alphal. Embo foumal 21 1-9.

Tsai C, Lin S, Ito M, Takagi N, Takada S \& Ferguson-Smith A 2002 Genomic imprinting contributes to thyroid hormone metabolism in the mouse embryo. Current Biology 12 1221-1226.

Tu HM, Legradi G, Bartha T, Salvatore D, Lechan RM \& Larsen PR 1999 Regional expression of the type 3 iodothyronine deiodinase messenger ribonucleic acid in the rat central nervous system and its regulation by thyroid hormone. Endocrinology 140 784-790.

Wallen-Mackenzie A, De Urquiza AM, Petersson S, Rodriguez FJ, Friling S, Wagner J, Ordentlich P, Lengqvist J, Heyman RA, Arenas E, Perlmann T, Sockanathan S \& Jessell TM 2003 Nurrl-RXR heterodimers mediate RXR ligand-induced signaling in neuronal cells. Retinoid receptor signaling in postmitotic motor neurons regulates rostrocaudal positional identity and axonal projection pattern. Genes and Development $\mathbf{1 7}$ 3036-3047.

Wolpert L 1989 Positional information revisited. Development 107 (Suppl) 3-12.

Received 5 July 2004

Accepted 19 July 2004 